\title{
Terapi Brief Mindfulness-Based Body Scan untuk Menurunkan Stres Atlet Bola Basket Wanita Profesional
}

\author{
DIAN KARTIKA AMELIA ARBI ${ }^{1 *} \&$ TRI KURNIATI AMBARINI ${ }^{2}$ \\ [1] Program Studi Magister Psikologi Profesi, Fakultas Psikologi Universitas Airlangga \\ [2] Departemen Psikologi Klinis dan Kesehatan Mental, Fakultas Psikologi Universitas Airlangga
}

\begin{abstract}
ABSTRAK
Tujuan dari intervensi ini adalah untuk menguji efektivitas terapi mindfulness-based body scan untuk mengurangi stres pada atlet bola basket wanita profesional. Intervensi ini menggunakan desain single subject design. Setiap partisipan intervensi berlatih 5 menit mindfulness breathing, 15 menit body scan, dan STOP sebagai teknik untuk menghadapi situasi stres. Pada setiap sesi terapi, partisipan akan diberikan skala perceived stress (PSS-10) untuk mengukur perubahan tingkat stres pada setiap sesinya. Hasil dari analisis visual dalam intervensi ini menunjukkan bahwa terdapat penurunan stres pada partisipan setelah terapi mindfulness-based body scan. Penulis menganalisis data dengan teknik percentage of non-overlapping data (PND) untuk mengukur effect size dan hasil analisis menunjukkan efek terapi yang relatif besar untuk menurunkan stres partisipan.
\end{abstract}

Kata kunci: atlet wanita, body scan, bola basket, mindfulness, stres

\begin{abstract}
The aim of our intervention was to examine the effectiveness of mindfulness-based body scan therapy to reduce stress in female professional basketball athletes. The intervention was performed using single subject design. We asked each participant to practice 5 minutes mindfulness breathing, 15 minutes body scan, and STOP as a technique to deal with stressful situations. At the end of each therapy session, we asked participants to fill perceived stress scale (PSS-10) to measure their stress level. We analyzed the data using visual analysis, and our findings indicated that there was significant stress decrease after mindfulness-based body scan therapy. We employed percentage of non-overlapping data (PND) analysis to measure effect size and it suggested that the therapy caused a rather large to reduce participants' stress level.
\end{abstract}

Keywords: basketball, body scan, female athlete, mindfulness, stress

INSAN Jurnal Psikologi dan Kesehatan Mental, 2018, Vol. 3(1), 1-12, doi: 10.20473/jpkm.v3i12018.1-12

Dikirimkan: 9 Februari 2018 Diterima: 13 Juli 2018 Diterbitkan: 26 Juli 2018

Editor: Rizqy Amelia Zein

*Alamat korespondensi: Kampus B Unair, Jalan Airlangga 4-6 Surabaya, Jawa Timur 60286. Pos-el: arbidian@gmail.com

Naskah ini merupakan naskah dengan akses terbuka dibawah ketentuan the Creative Common Attribution License (http://creativecommons.org/licenses/by/4.0), sehingga penggunaan, distribusi, reproduksi dalam media apapun atas artikel ini tidak dibatasi, selama sumber aslinya disitir dengan baik. 


\section{PEN D A H U L U A N}

Atlet yang bermain dalam kompetisi profesional memiliki tantangan di berbagai hal. Tantangan dan tuntutan yang harus dihadapi oleh atlet profesional meliputi kondisi kompetisi yang penuh tekanan, tekanan penonton, pengawasan publik melalui media elektronik, cetak, maupun sosial, serta dinamika kelompok dalam olahraga beregu (Rice, dkk., 2016). Rowbottom (2000 dalam Gustafsson, 2007) menambahkan bahwa atlet dituntut untuk peningkatan dan innovasi strategi, serta menjaga dan meningkatkan nutrisi. Atlet secara berkelanjutan terus dievaluasi kondisi fisik dan peningkatan penampilannya selama mejalani latihan dan kompetisi. Latihan yang terus menerus dan berkelanjutan memberikan tekanan baik fisik maupun psikologis kepada atlet, hingga mempengaruhi kesejahteraan psikis dan fisik. Kondisi ini dapat berlanjut pada simptom overtraining dan burnout (Saw, dkk., 2015). Kondisi stres psikososial dari atlet, seperti tuntutan penampilan, permasalahan keuangan, serta relasi sosial juga turut mempengaruhi penampilan atlet (Brown, dkk., 2006).

Atlet wanita memiliki tingkat stres yang tinggi terkait dengan hubungan dengan pelatih dibandingkan dengan atlet pria (Anshel, dkk., 2009). Pada atlet wanita, stres memiliki resiko yang lebih besar di bandingkan dengan laki-laki. Hal tersebut berkaitan dengan kondisi fisiologis dari perempuan. Di dunia kesehatan olahraga terdapat istilah sindrom triad pada atlet perempuan. Sindrom triad merupakan sebuah sindrom gangguan spektrum yang berkaitan dengan rendahnya ketersediaan energi dalam tubuh, gangguan menstruasi, dan kepadatan tulang (Nazem \& Ackerman, 2012). Mosavat, dkk. (2013) menjelaskan bahwa atlet wanita yang melakukan olahraga dengan intensitas tinggi beresiko mengalami perubahan hormonal yang berakibat pada gangguan menstruasi. Gangguan tersebut disebabkan oleh kurangnya cadangan energi dalam tubuh akibat kurangnya asupan energi namun banyak energi dikeluarkan pada saat latihan. Hal ini diperparah jika atlet mengalami stres, maka akan memunculkan hormon stres pada tubuh. Hormon stres serta kurangnya cadangan energi akan mempengaruhi siklus menstruasi dan meningkatkan resiko amenorea atau siklus haid yang memanjang. Dampak dari amenorea ini adalah rendahnya produksi estrogen oleh ovarium, sehingga berdampak pada kepadatan tulang dan mengakibatkan resiko cedera yang meningkat.

Lazarus dan Folkman (1984) menyebutkan bahwa stres psikologis muncul dikarenakan adanya persepsi terhadap sesuatu yang dianggap mengancam. Telah disebutkan sebelumnya bahwa sumber stres pada atlet profesional adalah kondisi fisik terkait latihan yang berulang, tekanan psikologis, dan juga sosialnya untuk meraih kemenangan. Pada kondisi stres, seseorang sering kali tidak menyadari sejauh mana hubungan antara sumber daya dalam diri mereka dan tekanan dari lingkungan. Hal ini membuat seseorang bereaksi secara otomatis, tanpa menyadari faktor protektif dalam diri, sehingga memunculkan respon yang kurang adaptif.

Salah satu pendekatan yang menekankan pada kesadaran untuk mengurangi stres adalah mindfulness. Mindfulness didefinisikan sebagai kesadaran yang timbul akibat kesengajaan untuk menyajikan dan menghadirkan pengalaman saat ini dengan cara yang tidak menghakimi dan menerima. Mindfulness merupakan kemampuan untuk mengarahkan perhatian seseorang dimana orang secara sengaja melakukan regulasi atas perhatian dari waktu ke waktu (Kabat-Zinn, 2005). Ketika individu mampu merespon stres dengan penuh kesadaran, maka di akan mampu mematahkan standar lama ketidaksadaran terkait dengan reaksi stres. Individu yang menyadari kondisi stres nya akan terbuka pada cara baru untuk bekerja dengan stres dan mengubahnya, dan memilih respon yang lebih adaptif (Kabat-Zinn, 2005). Individu yang tidak menyadari reaksi stres internal tidak akan mengetahui cara untuk mengekspresikan diri dalam pikiran, sensasi, dan emosi. Pada tahap ini individu akan menjadi tidak seimbang. Kesadaran atas kondisi stres secara otomatis membuat indivdu terkoneksi dan mampu mengenali apa yang dia alami. Seseorang menjadi lebih sadar akan keadaan batin, pikiran, emosi, sensasi, dan proses mental. Hal ini akan membuat seseorang lebih mampu mengatasi situasi stres, memiliki pola tidur yang baik, hingga meningkatkan harga diri (Stahl \& Goldsteinl, 2010).

INSAN Jurnal Psikologi dan Kesehatan Mental

2018, Vol. 3(1), 1-12

doi: 10.20473/jpkm.v3i12018.1-12

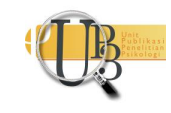




\section{Terapi Mindfulness-Based Body Scan}

Hasil penelitian Yadav (2017) menunjukkan bahwa brief mindfulness dengan praktek body scan efektif untuk menurunkan stres pada pasien ketergantungan alkohol. Ussher, dkk. (2012) menggunakan brief mindfulness dengan praktek body scan terbukti dapat menurunkan stres pada pasien dengan nyeri kronis. Pada intervensi ini, peneliti menggunakan desain intervensi Brief Mindfulness-Based Body Scan untuk menurunkan stres pada atlet bola basket wanita profesional. Praktek body scan dipilih dikarenakan body scan merupakan komponen kunci dari mindfulness, yang mengajarkan fokus pada momen saat ini dengan mengobservasi nafas, sensasi tubuh, dengan menerima apa pun yang disadari tanpa menghakiminya (Kabat-Zinn, 2005). Stahl dan Goldstein (2010) juga menyebutkan bahwa hubungan substansial dan signifikan antara mindfulness dan pengurangan stres ini berpusat di dalam hubungan pikiran dan tubuh. Berdasarkan hasil penelitian dari Call, dkk. (2013) di dapatkan hasil bahwa body scan lebih signifikan menurunkan stres di bandingkan praktek mindfulness hatha yoga.

\section{E T O D E}

\section{Prosedur Intervensi}

Seluruh partisipan diminta untuk menandatangi informed consent sebelum menjalani seluruh rangkaian intervensi. Selama 4 minggu mereka menjalani program intervensi mindfulness-based body scan. Sesi intervensi ini disusun berdasarkan mindfulness-based stres reduction therapy dari Kabat-Zinn (2005). Intervensi ini terdiri dari psikoedukasi, praktek mindfulness, dan membangun kesadaran atas kondisi diri. Pada setiap akhir sesi partisipan diukur tingat stres nya untuk melihat perubahan kondisi partisipan. Partisipan dalam intervensi ini akan diberikan penugasan mandiri berupa praktek mindfulness yang harus dikerjakan di rumah secara mandiri. Berikut ini adalah gambaran dari masingmasing sesi:

Sesi 1: Pengenalan. Pada sesi awal ini partisipan akan dijelaskan mengenai keseluruhan proses terapi, meliputi tujuan terapi, proses terapi, serta waktu dan durasi terapi. Pada sesi ini juga akan diberikan dan dijelaskan poin-poin dalam informed consent. Penulis serta partisipan selanjutnya akan bersamasama menandatangi informed consent.

Sesi 2: Mengungkapkan kondisi diri. Sesi ini memberikan kesempatan bagi partisipan untuk menceritakan kondisi atau hal yang membuat merasa tidak nyaman atau tertekan. Partisipan juga diminta untuk mengidentifikasi respon yang muncul saat dia berada pada kondisi yang menekan. Hal ini bertujuan untuk membuat partisipan lebih menyadari kondisi stres yang sedang di hadapi. Hal ini bertujuan untuk membuat partisipan lebih menyadari kondisi stres yang sedang di hadapi dan juga respon yang dia muncul.

Sesi 3: Menyadari kondisi saat ini. Sesi ini merupakan sesi psikoedukasi mengenai stres dan mindfulness. Peneliti akan memberikan penjelasan mengenai kondisi stres, ciri-ciri stres, penyebab serta dampak stres. Penjelasan stres pada sesi ini juga akan dijelaskan dampak stres pada kegiatan olahraga yang sedang dijalani. Partisipan juga akan dijelaskan mengenai pengertian mindfulness dan kaitannya dengan stres. Metode yang digunakan pada sesi ini tidak hanya sekedar ceramah, namun juga diskusi antara penulis dengan partisipan. Pada sesi ini partisipan juga akan menjalani praktek mindfulness breathing sebagai praktek awal mindfulness.

Sesi 4: Menghentikan kebiasaan respon otomatis. Tujuan sesi ini adalah belajar untuk menyadari kecenderungan kita untuk menilai situasi sebagai sesuatu yang baik atau buruk, dan tetap hadir sehingga kita dapat merespon secara sadar dan bukan secara otomatis. Praktek utama yang digunakan untuk melatih meningkatkan kesadaran adalah body scan dengan mengamati bagian-bagian tubuh dan

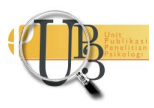


menyadari apa saja yang dirasakan oleh tubuh kita. Ketika kita berada pada kondisi sadar, maka diharapkan akan lebih mampu untuk memilih respon yang adaptif serta efektif. Praktek mindfulness yang digunakan untuk menghentikan respon otomatis adalah STOP. Praktek ini memberi kesempatan untuk menyadari apa yang kita alami. Hal ini bertujuan agar kita tidak terjebak dalam pikiran, sensasi, atau perasaan yang tidak membantu (Stahl \& Goldstein 2010).

Sesi 5: Evaluasi. Tujuan dari sesi ini adalah megevaluasi keseluruhan sesi. Pada sesi ini partisipan diminta untuk mengidentifikasi fokus dan tujuan hidupnya. Identifikasi ini berguna untuk menetapkan fokus yang harus dijalani oleh partisipan setelah sesi ini. Peneliti dan partisipan akan bersama-sama mengevaluasi jalannya seluruh sesi dalam terapi ini. Peneliti dan partisipan juga akan secara bersamasama mengambil kesimpulan dan pembelajaran dari hasil terapi yang telah dijalankan.

\section{Partisipan Intervensi}

Partisipan dalam intervensi ini sejumlah 4 orang atlet bola basket wanita profesional. Usia partisipan antara 22 hingga 27 tahun. Seluruh partisipan tergabung dalam satu klub bola basket profesional. Intervensi ini telah disetujui oleh tim manajemen dari klub dan juga pelatih. Sebelum intervensi dijalankan peneliti bertemu dengan tim manajemen dan juga pelatih untuk mendapatkan gambaran kondisi atlet pada klub. Hasil dari pengukuran awal ini didapatkan 6 atlet yang memiliki tingkat stres tinggi. Empat atlet bersedia menjadi partisipan dan mengisi informed consent, sedangkan dua lainnya tidak bersedia. Empat partisipan yang bersedia mengikuti proses intervensi, berhasil mengikuti seluruh sesi dalam intervensi ini.

\section{Desain Intervensi}

Desain intervensi yang digunakan adalah dengan menggunakan single subject design. Pada single subject design dilakukan pengukuran secara berulang, untuk melihat dampak perubahan dalam perlakuan eksperimental terhadap partisipan di bawah berbagai kondisi intervensi (James, 2016). Pada single subject design pengukuran variabel terikat atau target perilaku dilakukan berulang-ulang dengan periode waktu tertentu misalnya perminggu, perhari, atau perjam. Perbandingan tidak dilakukan antar individu maupun kelompok tetapi dibandingkan pada partisipan yang sama dalam kondisi yang berbeda. Kondisi yang dimaksud adalah kondisi baseline dan kondisi eksperimen (intervensi) (Sunanto dkk, 2005). Intervensi ini menggunakan single subject design, kategori reversal dengan desain A-B.

\section{Pengukuran Efektivitas Intervensi}

Perceived Stress Scale (PSS) merupakan skala yang dibuat oleh Cohen, dkk. (1988), dengan tujuan mengukur stres yang tidak spesifik yang dirasakan seseorang dalam situasi tertentu atau situasi kehidupan sehari-hari. Skala ini dibuat berdasarkan model stres transaksional Lazarus dan Folkman (1984). Model stres transaksional Lazarus dan Folkman (1984) berpendapat bahwa persepsi stres individu berasal dari ketidakseimbangan antara penilaian seseorang atas tuntutan situasional dan sumber daya coping. Perceived Stres Scale (PSS-10) terdiri dari tiga dimensi, yakni unpredictable, uncontrollable, dan overloading. Uji reliabilitas PSS-10 yang dilakukan di dapatkan reliabilitas sebesar 0.846 . 


\section{Analisis Efektivitas Intervensi}

Analisis data akan dilakukan dalam dua tahapan, yakni yakni yang pertama menggunakan visual analysis. Visual analysis merupakan analisis data secara visual yang mengacu pada representasi grafis yang akurat dari berbagai data pengukuran. Data tersebut diambil dari hasil pengamatan di awal dan pada fase perlakuan yang berbeda untuk secara jelas menunjukkan pola, tingkat dan kecenderungan perubahan perilaku yang ditunjukkan oleh partisipan. Data diambil pada semua fase pengamatan dengan referensi khusus mengenai perbedaan antara pra-intervensi (baseline) dan fase atau sesi intervensi (James, 2016).

Analisis kedua yang dilakukan adalah melakukan uji effect size dengan Percentage of Non-Overlapping Data (PND). PND menrupakan salah satu alternatif untuk melakukan uji effect size pada single case research design (Lenz, 2013). PND dikonseptualisasikan sebagai persentase data pada fase pengamatan atau intervensi yang melebihi satu titik penting dalam fase garis baseline (Lenz, 2013). Scruggs and Mastropieri (1998) menyebutkan bahwa metode non-overlap menghasilkan proporsi data yang dinyatakan dalam format desimal yang berkisar antara nol dan satu. Skor tersebut merupakan hasil dari pembagian jumlah data non-overlapping dengan seluruh data pada fase intervensi. Skor yang lebih tinggi menunjukkan efek intervensi yang lebih besar dan skor yang lebih rendah mewakili intervensi yang kurang efektif. Scruggs dan Mastropieri (1998) mengemukakan bahwa effect size lebih dari 0.90 merupakan indikasi intervensi yang sangat efektif, yang berkisar 0.70-0.89 mewakili efektivitas sedang, mereka antara 0.50-0.69 masih bisa diperdebatkan, dan skor kurang dari 0.5 dianggap tidak efektif. Data dianalisis dengan menggunakan program IBM SPSS for Windows versi 20.

\section{ANALISIS EFEKTIVITAS INTERVENSI}

Analisis Visual

Analisis awal yang digunakan pada intervensi ini adalah visual analysis. Hasil analisis visual menunjukkan penurunan nilai rerata dari fase baseline dibandingkan nilai rerata fase intervensi pada seluruh partisipan.

Partisipan 1 memiliki nilai rerata skor stres 22 pada fase baseline. Pada fase intervensi skor rerata partisipan 1 mengalami penurunan skor rerata stres menjadi 13.75. Grafik 1 memuat perbandingan skor rerata stres pada partisipan 1 tersebut menunjukkan bahwa partisipan mengalami penurunan stres setelah menjalani terapi.

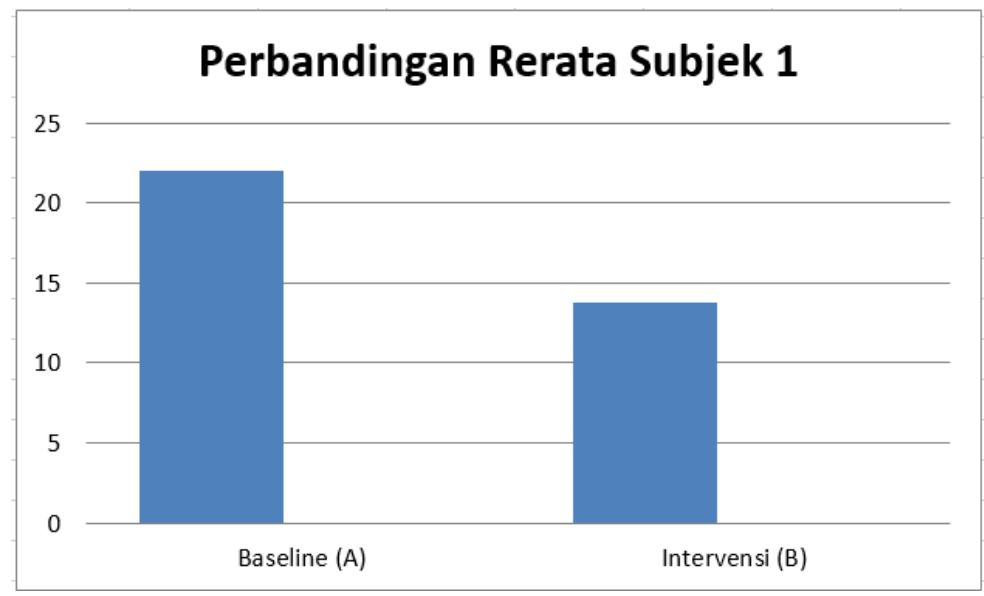

Grafik 1. Perbandingan Rerata Level Stres Partisipan 1

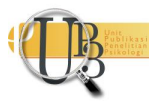


Grafik perbandingan skor rerata partisipan 2 menunjukkan rerata sebesar 23 pada fase baseline, dan turun menjadi 15.5 pada fase intervensi. Hal tersebut menunjukkan bahwa terdapat penurunan skor stres yang dialami partisipan 2 setelah menjalani terapi.

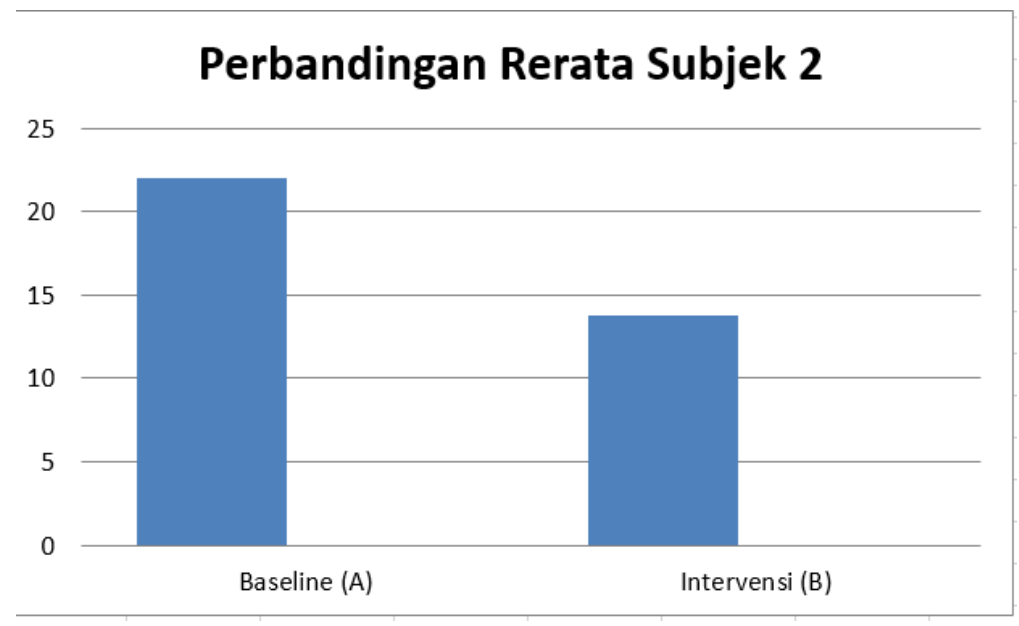

Grafik 2. Perbandingan Rerata Level Stres Partisipan 2

Pada partisipan 3, grafik rerata menunjukkan penurunan dari skor 26 menjadi 18.75 pada fase intervensi. Hasil tersebut menunjukkan bahwa partisipan mengalami penurunan stres setelah menjalani terapi.

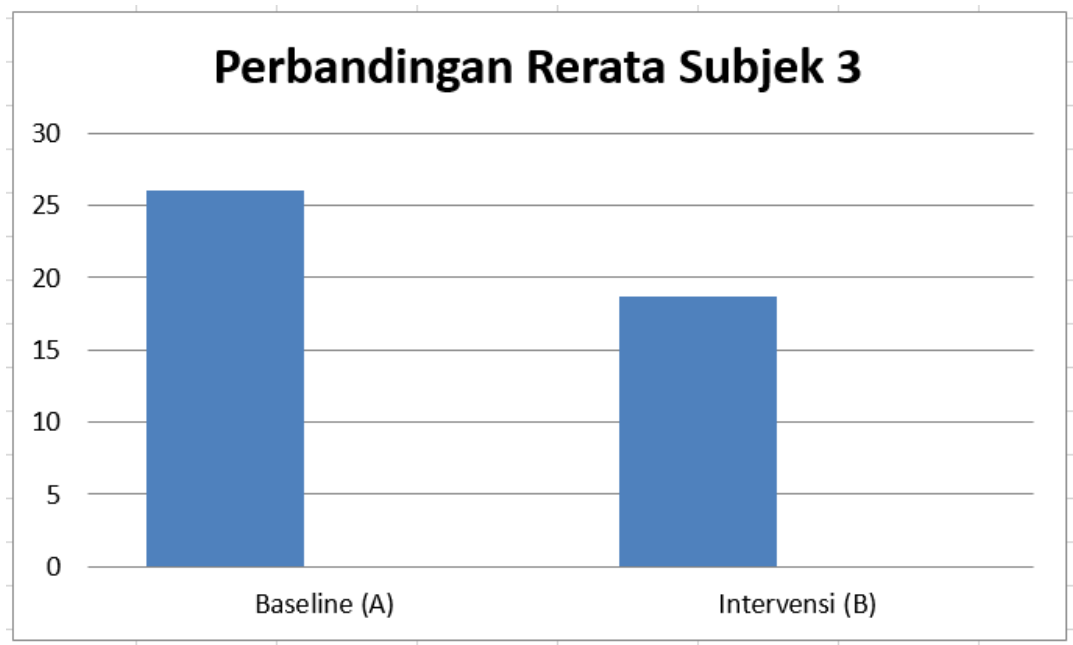

Grafik 3. Perbandingan Rerata Level Stres Partisipan 3

Pada partisipan 4, skor baseline sebesar 23 turun menjadi 13.5 pada fase intervensi. Penurunan skor tersebut menunjukkan bahwa terdapat penurunan kondisi stres pada partisipan 4 setelah menjalani terapi. 


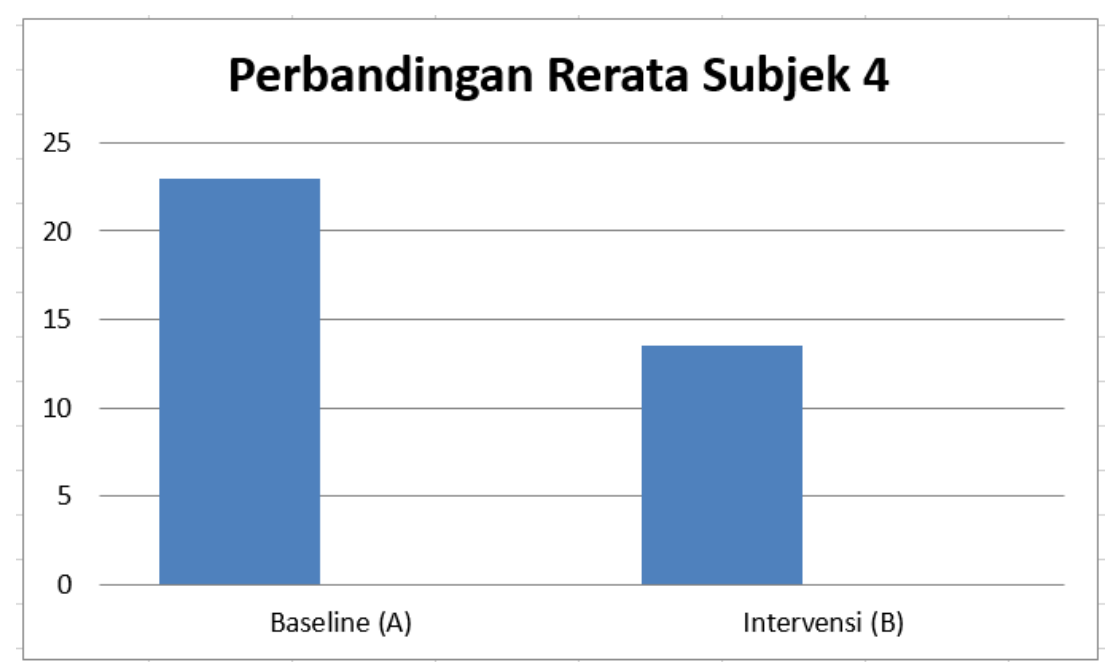

Grafik 4. Perbandingan Rerata Level Partisipan 4

Analisis Percentage of Non-Overlapping Data (PND)

Analisis kedua yang dilakukan adalah melakukan uji effect size dengan teknik PND. Pada analisis ini akan dilihat persentase data yang overlap dari masing-masing partisipan dalam serangkaian fase baseline dan intervensi. Berikut ini adalah grafik PND dari masing-masing partisipan:

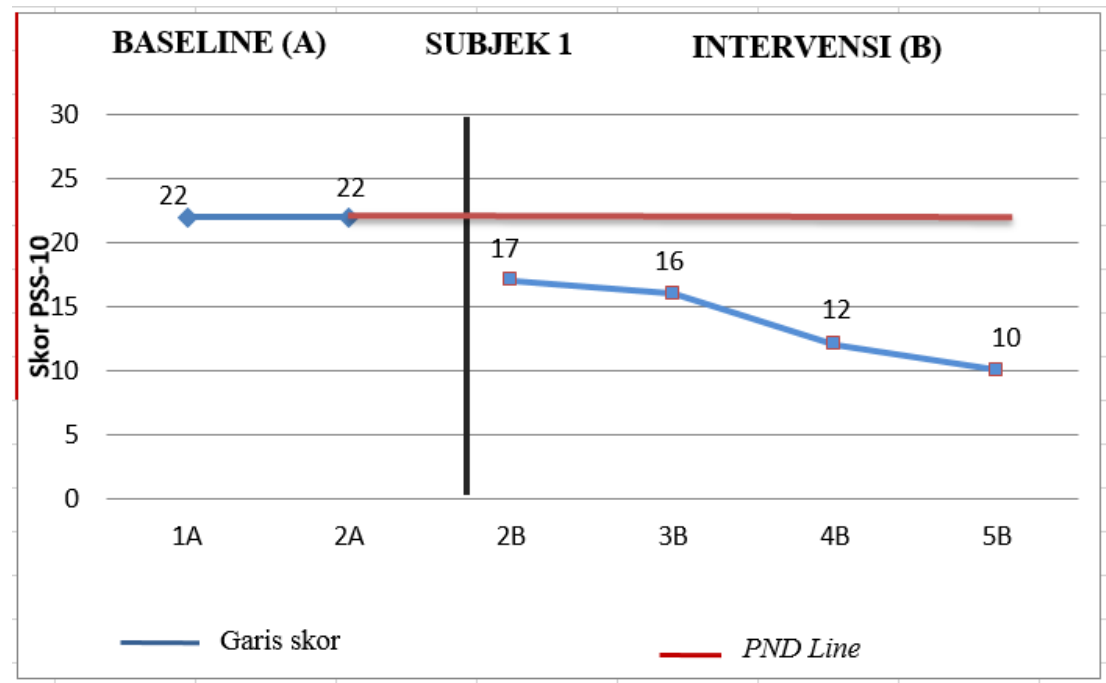

Grafik 5. Grafik PND Partisipan 1

Berdasarkan grafik PND pada partisipan 1 dapat dilihat bahwa seluruh data atau skor pada fase intervensi berada di bawah fase baseline. Hal ini menunjukkan bahwa tidak ada data overlapping yang muncul pada partisipan 1, sehingga besaran effect size pada partisipan 1 adalah 1 , yang berarti sangat efektif. 


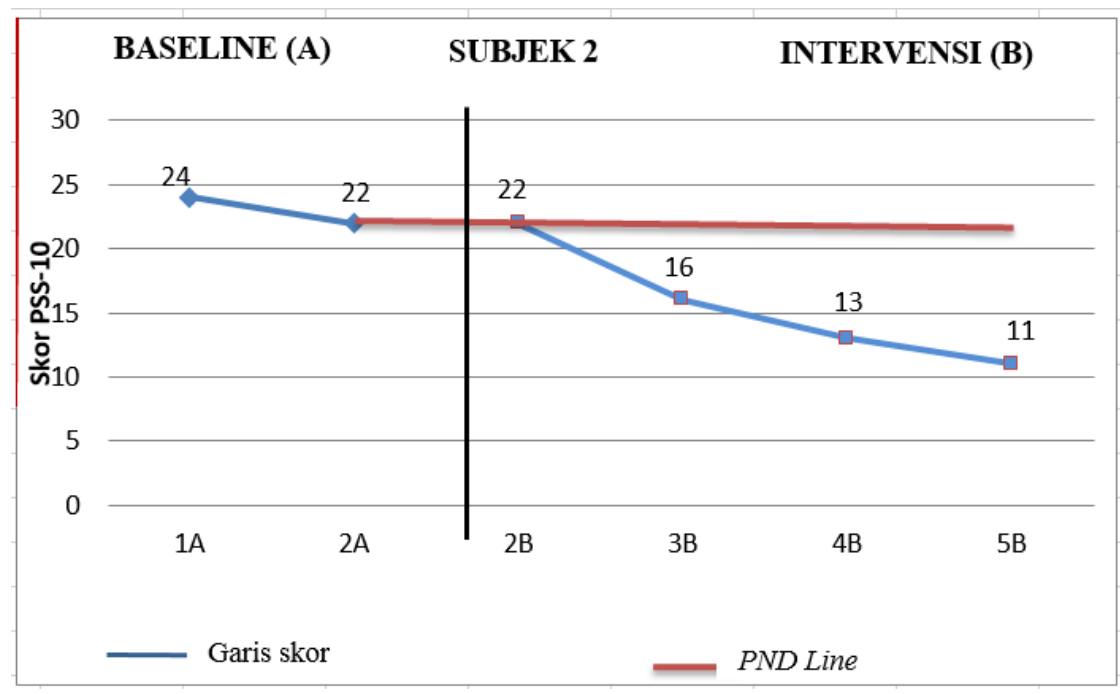

Grafik 6. Grafik PND Partisipan 2

Pada partisipan 2 terdapat satu data atau skor pada fase intervensi yang overlapping dengan data pada fase baseline. Dengan demikian terdapat 3 dari 4 data fase intervensi yang berada di bawah data pada fase baseline, Sehingga besaran effect size pada partisipan 2 adalah sebesar 0.75 , yang termsauk pada kategori sedang.

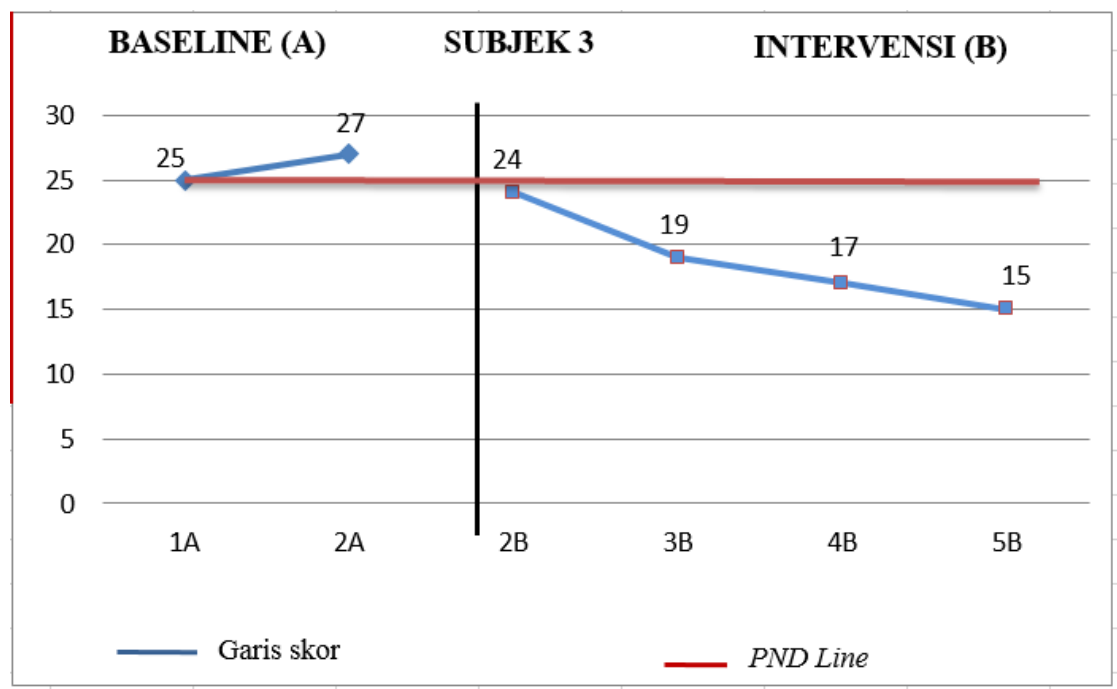

Grafik 7. Grafik PND Partisipan 3

Grafik PND pada partisipan 3 menunjukkan bahwa seluruh data atau skor pada fase intervensi berada di bawah fase baseline. Hal ini menunjukkan bahwa tidak ada data overlapping yang muncul pada partsipan 3, sehingga besaran effect size pada partisipan 3 adalah 1, yang berarti sangat efektif.

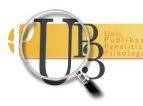




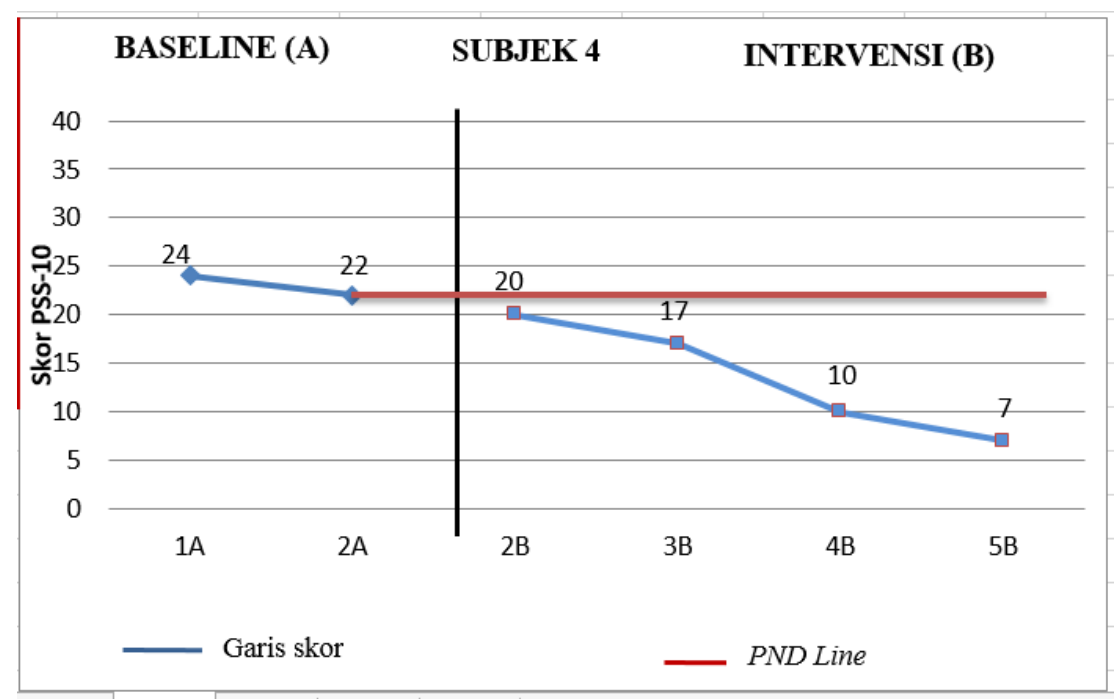

Grafik 8. Grafik PND Partisipan 4

Pada partisipan 3 seluruh data atau skor pada fase intervensi berada di bawah fase baseline. Hal ini menunjukkan bahwa tidak ada data overlapping yang muncul pada partsipan 4 , sehingga besaran effect size pada partisipan 4 adalah 1 , yang berarti sangat efektif.

\section{I S K U S I}

Hasil dari analisis visual pada seluruh partisipan menunjukkan kecenderungan arah grafik atau tren menurun. Seluruh partisipan juga menunjukkan perubahan kategori tingkat stres dari kategori stres tinggi pada fase baseline berubah menjadi tingkat stres sedang di akhir fase intervensi. Hal ini menunjukkan bahwa seluruh partisipan dalam intervensi ini mengalami penurunan tingkat stres setelah diberikan terapi Brief Mindfulness-Based Body Scan. Hasil ini juga diperkuat dengan penghitungan data overlap pada masing-masing partisipan yang menunjukkan rentang data overlap 00.25. Berdasarkan rentang data overlap tersebut dapat simpulkan bahwa terapi BriefMindfulness-Based Body Scan dalam intervensi ini memberikan pengaruh terhadap penurunan tingkat stres partisipan, yakni sebesar 0.75-1, sehingga pemberian terapi Brief Mindfulness-Based Body Scan pada penuruan stress pada atlet bola basket wanita profesional dalam intervensi ini memiliki efektifitas sedang hingga sangat efektif.

Dalam intervensi ini, terapi Brief Mindfulness-Based Body Scan dapat menurunkan stres pada partisipan disebabkan oleh beberapa hal. Pada sesi awal terapi partisipan diminta untuk menyadari dan mengungkapkan kondisi-kondisi yang membuat partisipan merasa tidak nyaman dan juga respon yang mereka munculkan. Proses ini membuat partisipan lebih sadar bagaimana kondisi stres mempengaruhi dirinya. Seluruh partisipan mampu untuk mengenali dan menyadari kondisi-kondisi yang menyebabkan stres beserta respon yang mereka munculnya. Proses ini dijelaskan oleh Stahl dan Goldstein (2010) sebagai proses refleksi diri dalam terapi mindfulness, dimana individu berlatih untuk menjadi lebih sadar akan kondisi stres yang sedang di alami. Kesadaran memungkinkan individu untuk melihat pengalaman diri dengan jelas, sehingga individu menjadi lebih sadar tentang bagaimana stres mempengaruhi dirinya. Saat berada pada kondisi sadar, individu dapat memilih respon yang lebih terampil dan adaptif untuk menghadapi stres.

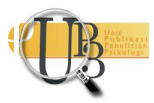


Praktek body scan yang digunakan pada terapi ini membantu individu untuk melakukan relaksasi pernafasan, dengan fokus menyeluruh pada tubuh yang bertujuan untuk mengembangkan konsentrasi sekaligus fleksibilitas perhatian secara bersamaan (Kabat-Zinn, 2005). Body scan juga membantu individu untuk relaksasi dan melemaskan otot, sehingga dapat menurunkan rasa nyeri dan distres pada individu (Ussher, dkk., 2012). Hasil dari pelaksanaan praktek ini membuat partisipan dalam intervensi ini merasa lebih tenang, dapat melemaskan otot-otot yang tegang karena aktifitas fisik yang mereka jalani. Mereka juga mengaku lebih nyenyak tidur setelah melakukan body scan dan mindfulness breathing. Salah satu partisipan juga mengaku baru menyadari kakinya sedang mengalami nyeri akibat kesalahan bergerak saat latihan setelah menjalani body scan. Praktek Brief Mindfulness Body Scan memberikan manfaat bagi atlet bola basket wanita untuk lebih menyadari sensasi fisik yang muncul akibat aktivitas fisik, sehingga tidak menimbulkan resiko yang besar seperti cedera.

Hasil refleksi partisipan terhadap praktek Brief Mindfulness Body Scan fokus pada tugas dan tujuan serta menyadari kondisi yang sedang kita hadapi. Atlet bola basket wanita profesional yang menjadi partisipan dalam intervensi ini merasa lebih menyadari fokus dan tujuan yang harus dia capai, serta menyadari tujuan dari hidupnya. Kesadaran akan tujuan hidup yang dimiliki membuat partisipan juga lebih menyadari hal-hal yang menjadi fokusya, dan hal mana saja yang mengangganggu fokus untuk mencapai tujuan. Kesadaran akan adanya hal yang menganggu akan membuat partisipan dapat segera mengembalikan fokusnya pada tujuan. Hasil ini sesuai penelitian dari Goodman, dkk. (2014) yang menyebutkan bahwa meningkatnya mindfulness akan membuat atlet memiliki tujuan yang lebih terarah, serta menurunkan perasaan stres.

Lazarus dan Folkman (1984) menyebutkan bahwa stres psikologis muncul dikarenakan adanya persepsi terhadap sesuatu yang dianggap ancaman. Pada kondisi ini, seseorang sering kali tidak menyadari sejauh mana hubungan antara sumber daya dalam diri mereka dan ancaman dari lingkungan. Terapi Brief Mindfulness-Based Body Scan selain mengajarkan praktek body scan, terapi ini juga meminta partisipan untuk menyadari kelebihan serta kekurangannya dalam dirinya. Hal ini bertujuan agar partisipan lebih menyadari sumber daya dan potensi yang dia miliki untuk menghadapi tantangan di lingkungan. Ketika individu mampu merespon stres dengan penuh kesadaran, maka dia akan mampu terbuka pada cara baru untuk menghadapi stres serta memilih respon yang lebih adaptif (Kabat-Zinn, 2005).

Tuntutan, tekanan kompetitif dan evaluasi atas performa serta kondisi fisik akan selalu diterima oleh atlet profesional bola basket. Kesadaran mengenai tekanan yang sedang dihadapi, kesadaran akan potensi serta sumber daya yang dimiliki akan membuat atlet lebih mampu memilih repon yang tepat untuk menghadapi tekanan. Kemampuan untuk melakukan mindfulness breathing dan body scan juga dapat membantu partisipan untuk lebih tenang dan meregangkan otot yang kaku akibat aktifitas olahraga. Kabat-Zinn (2005) menyebutkan dengan mindfulness kesadaran dihadirkan secara sengaja memperhatikan hal-hal kecil yang biasanya tidak pernah pikirkan atau perhatikan. Mindfulness mengembangkan kontrol dan kebijaksanaan dalam hidup kita, yang didasarkan pada kapasitas mental kita untuk relaksasi, perhatian, kesadaran, dan menghasilkan insight untuk respon stres yang lebuh tepat.

\section{S I M P U L A N}

Berdasarkan hasil analisis efektivitas intervensi yang telah dilakukan, maka dapat disimpulkan bahwa Brief Mindfulness-Based Body Scan mampu memberikan efektifitas sedang sampai sangat efektif terhadap penurunan kondisi stres pada masing-masing partisipan. Perubahan yang dirasakan oleh atlet bola basket wanita profesional adalah mereka merasa lebih tenang, lebih menyadari tekanan yang

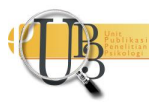


sedang dihadapi, serta memiliki kesadaran akan potensi serta sumber daya yang dimiliki untuk dapat memberikan respon yang adaptif terhadap stres.

\section{PUSTAKA ACUAN}

Anshel, M.H., Sutarso, T., \& Jubenville, C. (2009). Racial and gender differences on sources of acute stress and coping style among competitive athletes. The Journal of Social Psychology, 149(2), 159-178.

Azwar, S. (2010). Reliabilitas dan Validitas. Yogyakarta: Pustaka Pelajar.

Brown, J.F., Wilson, M.A., \& Sharp, N.C. (2006). "Down but Not out”: An Exploration of the Psychological Factors That Impact the Unexplained Underperformance Syndrome (UPS). International Journal of Sports Science \& Coaching, 1(2), 163-176.

Call, D., Mirron, L., \& Orcutt, H. (2013). Effectiveness of Brief Mindfulness Techniques in Reducing Symptoms of Anxiety and Stress. Mindfulness, 4 (2).

Chiesa, A., \& Serretti, A. (2009). Mindfulness-based stress reduction for stress management in healthy people: a review and meta-analysis. The Journal of Alternative and Complementary Medicine, 15(5), 593-600.

Cohen, S. \& Willamson, G. (1988). Perceived stress in a probability sample of the United State. In: Spacapan S, Oskam S. (Editor). The social psychology of health. Newbury Park, CA: SAGE.

Goodman, F.R., Kashdan, T.B., Mallard, T.T., \& Schumann, M. (2014). A brief mindfulness and yoga intervention with an entire NCAA Division I athletic team: An initial investigation. Psychology of Consciousness: Theory, Research, and Practice, 1(4), 339.

Gustafsson, H. (2007). Burnout in competitive and elite athletes (Disertasi Doktoral, Örebro universitetsbibliotek).

James, K.P. (2016). Single-subject research method: The needed simplification. British Journal of Education, 4(6), 68-95.

Kabat-Zinn, J. (2005). Full Catastrophe Living. New York: Bantam Dell.

Lenz, A.S. (2013). Calculating effect size in single-case research: A comparison of nonoverlap methods. Measurement and Evaluation in Counseling and Development, 46(1), 64-73.

Lazarus, R.S. \& Folkman, S. (1984). Stress: Appraisal and coping. New York: Springer

Mosavat, M., Mohamed, M., \& Mirsanjari, M.O. (2013). Effect of exercise on reproductive hormones in female athletes. International Journal of Sport and Exercise Science, 5(1), 7-12.

Nazem, T.G., \& Ackerman, K.E. (2012). The female athlete triad. Sports Health, 4(4), 302-311.

Rice, S.M., Purcell, R., De Silva, S., Mawren, D., McGorry, P.D., \& Parker, A.G. (2016). The mental health of elite athletes: a narrative systematic review. Sports Medicine, 46(9), 1333-1353.

Saw, A.E., Main, L.C., \& Gastin, P.B. (2015). Monitoring the athlete training response: subjective selfreported measures trump commonly used objective measures: a systematic review. Br J Sports Med, 50, 281-191.

Scruggs, T.E., \& Mastropieri, M.A. (1998). Summarizing single-subject research: Issues and applications. Behavior modification, 22(3), 221-242.

INSAN Jurnal Psikologi dan Kesehatan Mental

2018, Vol. 3(1), 1-12

doi: 10.20473/jpkm.v3i12018.1-12

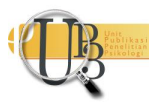


Sunanto, J., Takeuchi, K., \& Nakata, H. (2005). Pengantar Penelitian dengan Partisipan Tunggal. University of Tsukuba: Center for Research on International Cooperation in Educational Development (CRIED).

Stahl, B., \& Goldstein, E. (2010). A Mindfulness-Based Stress Reduction Workbook. Oakland: New Harbinger Publication.

Ussher, M., Spatz, A., Copland, C., Nicolaou, A., Cargill, A., Amini-Tabrizi, N., \& McCracken, L.M. (2014). Immediate effects of a brief mindfulness-based body scan on patients with chronic pain. Journal of Behavioral Medicine, 37(1), 127-134.

Yadav, S. (2017). Effectiveness of Mindfulness Based Body Scan Meditation: A Case Study of Alcohol Dependence Patient. International Journal of Indian Psychology, 4(3), 58-64. 